\title{
Effect of iron deficiency on the digestive utilization of iron, phosphorus, calcium and magnesium in rats
}

\author{
BY I. PALLARÉS, F. LiSBONA, I. LOPEZ ALIAGA, M. BARRIONUEVO, \\ M. J. M. ALFÉREZ AND M. S. CAMPOS \\ Departamento de Fisiologí, Facultad de Farmacia, Universidad de Granada, E-18071 Granada, \\ Spain
}

(Received 27 January 1992-Accepted 9 November 1992)

\begin{abstract}
The influence of the source of dietary $\mathrm{Fe}$ (ferric citrate alone or mixed with bovine blood at a proportion of $1: 1(\mathrm{v} / \mathrm{v})$ ) on the digestive utilization of $\mathrm{Fe}, \mathrm{P}, \mathrm{Ca}$ and $\mathrm{Mg}$, and on haemoglobin regeneration efficiency (HRE) was investigated in control and Fe-deficient rats. Diet $A$ contained (by analysis) $43 \cdot 5 \mathrm{mg} \mathrm{Fe} / \mathrm{kg}$ diet (as ferric citrate), and diet $B$ contained $44.3 \mathrm{mg} \mathrm{Fe} / \mathrm{kg}$ diet (ferric citrate-bovine blood). In Fedeficient rats fed on diet $A$ or $B$ the apparent digestibility coefficient (ADC) of Fe increased by 42.3 and 45.7\% respectively. The $\mathrm{ADC}$ of $\mathrm{Ca}$ and $\mathrm{Mg}$ decreased significantly in $\mathrm{Fe}$-deficient rats regardless of the source of dietary $\mathrm{Fe}$. The HRE increased by $72.9 \%$ in Fe-deficient rats fed on diet $\mathrm{A}$, and by $91.1 \%$ in Fe-deficient animals fed on diet B. In Fe-deficient rats fed on Fe for $10 \mathrm{~d}$ the values of haematological variables approached normality. However, serum $F e$ remained low, indicating that Fe reserves were still depleted. A deficient dietary supply of $\mathrm{Fe}$ for $30 \mathrm{~d}$ did not significantly modify the numbers of circulating leucocytes.
\end{abstract}

Digestibility: Iron: Phosphorus: Calcium: Magnesium: Rat

Nutritional anaemias, particularly $\mathrm{Fe}$ deficiency, are among the most widespread nutritional problems in the world, affecting primarily developing countries, and to a lesser degree, industrialized countries. According to the World Health Organization these disorders affect between 15 and $20 \%$ of the world's population.

Many forms of dietary $\mathrm{Fe}$ have been described, together with their effects on $\mathrm{Fe}$ absorption (Mahoney \& Hendricks, 1984; Martinez-Torres et al. 1986; Beutler, 1988; Gordon \& Godber, 1989; Zhang et al. 1989, 1991). Many studies have examined the interactions of $\mathrm{Fe}$ with other elements added to the diet to increase or decrease $\mathrm{Fe}$ absorption; the consensus is that animal proteins increase the absorption of non-haem(Layrisse et al. 1968, 1969; Martínez-Torres \& Layrisse, 1971; Hallberg et al. 1979) and haem-Fe (Gordon \& Godber, 1989).

Interactions between $\mathrm{Fe}$ and trace elements, including $\mathrm{Zn}, \mathrm{Mn}, \mathrm{Cu}, \mathrm{Cd}, \mathrm{Co}$ (Flanagan et al. 1978; Hamilton et al. 1978; Lönnerdal et al. 1981; Solomons et al. 1983; Lönnerdal, 1989; O'Dell 1989) and $\mathrm{Pb}$ (Conrad \& Barton, 1978; Flanagan et al. 1980) have also been well characterized. However, little is known about $\mathrm{Fe}-\mathrm{Ca}, \mathrm{Fe}-\mathrm{Mg}$ or $\mathrm{Fe}-\mathrm{P}$ interactions (Apte \& Venkatachalam, 1964; Monsen \& Cook, 1976; Snedeker et al. 1982; Mahoney et al. 1985; Dawson-Hughes et al. 1986; Deehr et al. 1990); because most of these studies were based on healthy individuals with raised protein levels, the interactions between $\mathrm{Fe}$ and these macronutrients in states of Fe deficiency concomitant with protein sufficiency have yet to be clearly elucidated.

The present article clarifies some of the interactions between $\mathrm{Fe}$ and $\mathrm{P}, \mathrm{Ca}$ and $\mathrm{Mg}$ in rats fed on a diet containing either non-haem-Fe in the form of ferric citrate, or haem- and non- 
haem-Fe in equal proportions (ferric citrate-bovine blood). In all experiments the dietary protein supplied to both control and Fe-deficient animals was sufficient to cover the minimum requirements for this species.

\section{MATERIALS AND METHODS \\ Experimental design}

The influence of two diets ( $\mathrm{A}$ and $\mathrm{B}$ ) on the digestive utilization of $\mathrm{Fe}, \mathrm{P}, \mathrm{Ca}$ and $\mathrm{Mg}$, and on haemoglobin regeneration efficiency (HRE), was studied in rats made Fe-deficient by feeding for $30 \mathrm{~d}$ with a diet prepared in our laboratory without Fe supplementation (diet $\mathrm{O}$ ), and in normal controls fed on diet A. A total of twenty-eight male rats were divided into four groups of seven animals each. Food intake, body weight, change in body weight, and intake, faecal excretion, absorption and apparent digestibility coefficient (ADC) of Fe, $\mathrm{P}, \mathrm{Ca}$ and $\mathrm{Mg}$ were determined in all subjects, as were plasma concentrations of $\mathrm{Fe}, \mathrm{Ca}$ and $P$, number of erythrocytes, packed cell volume, haemoglobin, leucocyte count and leucocyte index (percentage of each type of leucocyte relative to the total number of leucocytes identified) in blood.

\section{Diets}

Table 1 summarizes the composition of diets $\mathrm{O}, \mathrm{A}$ and $\mathrm{B}$ on a dry weight basis. In diet $\mathrm{A}$, Fe was supplied by the addition of $210 \mathrm{mg}$ ferric citrate (about $190 \mathrm{mg} \mathrm{Fe} / \mathrm{g}$ ) $/ \mathrm{kg}$ diet. The amount of Fe supplied by diet B was similar, the only difference between the two being that the latter diet contained equal amounts of ferric citrate and bovine blood rather than ferric citrate alone.

Subsequent analysis, before the experiment was started, showed that diet A contained (mg/ $\mathrm{kg}$ diet) : Fe 43.5, P 4500, Ca 5250, Mg 570. The corresponding values for diet B were (mg/kg diet) Fe 44.3, P 5860, Ca 6000, Mg 530.

\section{Animals}

The subjects were 4-week-old (recently weaned) male Wistar albino rats with an initial body weight of 50-65 g, reared in the University of Granada Laboratory Animal Service. The animals were divided into groups of seven rats each, which were housed from day 0 of the experiment in individual metabolism cages designed for the separate collection of faeces and urine; the cages were located in a well-ventilated, thermostatically controlled room $\left(21^{\circ}\right)$ with $12 \mathrm{~h}$ light- $12 \mathrm{~h}$ dark periods.

Expt $C-A$. After feeding the semi-synthetic diet A (ferric citrate) for $30 \mathrm{~d}$, diet A was supplied again during the experimental period.

Expt $C$-B. After feeding diet A for $30 \mathrm{~d}$, diet B (ferric citrate-bovine blood) was supplied during the experimental period.

Expt $F-A$. After feeding diet $\mathrm{O}$ (without Fe supplement) for $30 \mathrm{~d}$, diet $\mathrm{A}$ was supplied during the experimental period.

Expt $F-B$. After feeding diet $\mathrm{O}$ for $30 \mathrm{~d}$, diet $\mathrm{B}$ was supplied during the experimental period.

In all experiments, Thomas \& Mitchell's (1923) biological technique was used. A period of $3 \mathrm{~d}$ was allowed for adaptation to the diet, followed by a $7 \mathrm{~d}$ experimental period when faeces were collected on alternate days. Food intake (the total amount consumed daily by each rat was determined by weighing the amounts of diet given, refused and spilled) and body weight were recorded at the beginning and at the end of the experimental period, that is on days 33 and 40 of all experiments. Throughout the experimental period all rats had free access to double-distilled water. On days 0,30 and 40 of all experiments tail blood was 
Table 1. Composition of the experimental diets $(\mathrm{g} / \mathrm{kg}$ dry weight $)$

\begin{tabular}{|c|c|c|c|}
\hline \multirow[b]{2}{*}{ Component } & \multirow[b]{2}{*}{$\mathrm{g} / \mathrm{kg}$ dry wt } & \multicolumn{2}{|c|}{ By analysis } \\
\hline & & Diet A & Diet B \\
\hline Choline chloride & 2 & - & - \\
\hline $\begin{array}{l}\text { Protein (casein }+50 \mathrm{mg} \\
\text { DL-methionine } / \mathrm{g} \text { ) }\end{array}$ & 120 & 120 & 123 \\
\hline Fibre (micronized cellulose) & 80 & - & - \\
\hline Fat (olive oil) & 40 & 41 & 43 \\
\hline Mineral supplement* & 35 & - & - \\
\hline Vitamin supplement & 10 & 一 & - \\
\hline $\begin{array}{l}\text { Equal parts of saccharose } \\
\text { and wheat starch to } 1 \mathrm{~kg}\end{array}$ & & & \\
\hline
\end{tabular}

* The mineral supplement contained $(\mathrm{g} / \mathrm{kg}): \mathrm{CaHPO}_{4} 500 \cdot 00, \mathrm{NaCl} 74 \cdot 00, \mathrm{C}_{6} \mathrm{H}_{5} \mathrm{~K}_{3} \mathrm{O}_{7} \cdot \mathrm{H}_{2} \mathrm{O} 220 \cdot 00, \mathrm{~K}_{2} \mathrm{SO}_{4}$ $52 \cdot 00, \mathrm{MgO} 24 \cdot 00, \mathrm{MnCO}_{3} . \mathrm{H}_{2} \mathrm{O}(430-480 \mathrm{mg} \mathrm{Mn} / \mathrm{g}) 3 \cdot 50, \mathrm{ZnCO}_{3}(700 \mathrm{mg} \mathrm{ZnO} / \mathrm{g}) 1 \cdot 60, \mathrm{CuCO}_{3} \cdot \mathrm{Cu}(\mathrm{OH})_{2} \cdot 2 \mathrm{H}_{2} \mathrm{O}$ $(530-550 \mathrm{mg} \mathrm{Cu} / \mathrm{g}) 0 \cdot 30, \mathrm{KIO}_{4} 0 \cdot 01, \mathrm{Na}_{2} \mathrm{SeO}_{3} .5 \mathrm{H}_{2} \mathrm{O} 0 \cdot 01, \mathrm{KCr}\left(\mathrm{SO}_{4}\right)_{2} .12 \mathrm{H}_{2} \mathrm{O} 0 \cdot 55$, and finely powdered sucrose to make up to $1000 \mathrm{~g}$.

$f$ The vitamin supplement contained $(\mathrm{g} / \mathrm{kg})$ : thiamine hydrochloride 0.6 , riboflavin 0.6 , pyridoxine hydrochloride 0.7 , nicotinic acid (nicotinamide equivalent) 3.0 , calcium pantothenate 1.6 , folic acid 0.2 , biotin 0.02 , cyanocobalamin 0.001 , retinol 0.12 , cholecalciferol $0.0025, \alpha$-tocopherol $4 \cdot 6$, menadione $0 \cdot 005$, and finely powdered sucrose to make up to $1000 \mathrm{~g}$.

collected after an overnight ( $12 \mathrm{~h}$ ) fast into tubes containing EDTA, and on day 40 of each experiment the animals were subjected to intraperitoneal urethane anaesthesia $(200 \mathrm{mg} / \mathrm{kg}$ body weight) and were then completely exsanguinated via an abdominal aorta cannula. All blood samples were centrifuged to separate plasma, which was frozen at $-30^{\circ}$ until analysed.

\section{Biological indices}

Percentage ADC was calculated with the formula:

$$
\text { percentage } \mathrm{ADC}=\frac{\text { absorbed }}{\text { intake }} \times 100
$$

where nutrient absorption $=$ intake - faecal excretion.

Haemoglobin regeneration efficiency (HRE) was calculated as follows (Zhang et al. 1989):

Haemoglobin-Fe $(\mathrm{mg})=$ body weight $(\mathrm{g}) \times \mathrm{ml} \mathrm{blood} / \mathrm{g}$ body weight (assumed to be $0.067 \mathrm{ml}$ ) $\times \mathrm{g}$ haemoglobin $/ \mathrm{ml}$ blood $\times \mathrm{mg} \mathrm{Fe} / \mathrm{g}$ haemoglobin (assumed to be $3.35 \mathrm{mg}$ ).

$$
\text { Percentage HRE }=\frac{\mathrm{mg} \text { haemoglobin-Fe }(\mathrm{final})-\mathrm{mg} \text { haemoglobin-Fe (initial) }}{\mathrm{mg} \mathrm{Fe} \text { consumed }} \times 100 .
$$

\section{Analytical methods}

Water contents of the diet and the faeces were determined by drying at $105 \pm 2^{\circ}$ until no further weight change was observed. Samples were ashed by calcination of $1-2 \mathrm{~g}$ samples at $450^{\circ}$; the resulting residue was extracted with $5 \mathrm{M}-\mathrm{HCl}$, and made up to an appropriate volume with double-distilled water for $\mathrm{Fe}$ and $\mathbf{P}$ analysis, or with lanthanum chloride solution $(5 \mathrm{~g} / \mathrm{l})$ for $\mathrm{Ca}$ and $\mathrm{Mg}$ analysis to avoid possible interference of $\mathrm{P}$. Atomic absorption spectrophotometry (Perkin-Elmer $1100 \mathrm{~B}$ ) was used to determine $\mathrm{Fe}$, $\mathrm{Ca}$ and $\mathrm{Mg}$; $\mathbf{P}$ was determined by visible light spectrophotometry using the technique of Fiske \& 
Table 2. Body weight in control and iron-deficient rats fed on diets with different sources of $\mathrm{Fe} \S$

(Mean values with their standard errors for seven rats)

\begin{tabular}{|c|c|c|c|c|c|c|}
\hline \multirow{3}{*}{$\begin{array}{l}\text { Treatment } \\
\text { group }\end{array}$} & \multicolumn{6}{|c|}{ Body-wt (g) at: } \\
\hline & \multicolumn{2}{|c|}{ Day 0} & \multicolumn{2}{|c|}{ Day 33} & \multicolumn{2}{|c|}{ Day 40} \\
\hline & Mean & $\mathrm{SE}$ & Mean & $\mathrm{SE}$ & Mean & $\mathrm{SE}$ \\
\hline $\mathbf{C}-\mathbf{A}$ & $55 \cdot 6$ & 1.5 & 237.5 & $2 \cdot 7$ & $289.5^{*}$ & $6 \cdot 1$ \\
\hline C-B & 57.9 & $2 \cdot 1$ & $248 \cdot 6$ & $4 \cdot 4$ & $302.0 \dagger$ & $4 \cdot 2$ \\
\hline $\mathrm{F}-\overline{\mathrm{A}}$ & $57 \cdot 0$ & $2 \cdot 1$ & 221.9 & $10 \cdot 8$ & $239 \cdot 1 \ddagger$ & $8 \cdot 1$ \\
\hline F-B & 58.1 & 1.8 & $246 \cdot 9$ & 4.0 & 262.9 & $4 \cdot 6$ \\
\hline
\end{tabular}

C-A, semi-synthetic diet A (ferric citrate) for $30 \mathrm{~d}$ followed by diet A for experimental period; C-B, diet A for $30 \mathrm{~d}$ followed by diet $\mathbf{B}$ (ferric citrate-bovine blood) for experimental period; F-A, diet $\mathrm{O}$ (no Fe supplement) for $30 \mathrm{~d}$ followed by diet $\mathrm{A}$ for experimental period; $\mathrm{F}-\mathrm{B}$, diet $\mathrm{O}$ for $30 \mathrm{~d}$ followed by diet $\mathrm{B}$ for experimental period. Mean values were significantly different from those for $\mathrm{F}-\mathrm{A}:{ }^{*} P<0.001$.

Mean value was significantly different from that for $\mathrm{F}-\mathrm{B}: \ddagger P<0.05 ; \dagger P<0.001$.

$\S$ For details of diets, see Table 1 and p. 610.

Subbarow (1925). N was determined by Kjeldahl's method, using a protein conversion factor of $6 \cdot 25$. Fat content was analysed by the Weibull-Berntrop gravimetric method (Weibull \& Berntrop, 1988).

Packed cell volume, erythrocyte and leucocyte counts, and haemoglobin level were obtained using a Symex CC-130 automatic cell counter. The leucocyte index was determined by microscopic observation of stained slides. Serum levels of $\mathrm{Fe}, \mathrm{Ca}$ and $\mathrm{P}$ were obtained by colorimetry (Trinder, 1956; Sarkar \& Chauhan, 1967; Drewes, 1972).

\section{Statistical treatment}

Values are given as means with their standard errors for each variable investigated. Comparisons were made between groups (control and Fe-deficient) and diets (A and B) by one- and two-way ANOVA. A $P$ value of less than 0.05 was considered significant.

\section{RESULTS}

\section{Body weight}

The weaned animals ranged in body weight from 50 to $65 \mathrm{~g}$. The animals were then allocated randomly to four experimental groups such that there were no significant differences between groups in body weight.

Body weight at the start of the experimental period was higher in rats fed on diet B, both in control and Fe-deficient rats (Table 2).

At the end of the experimental period both the type of diet and Fe deficiency affected body weight, which was higher in control and Fe-deficient rats that consumed diet $B$; the differences were only significant between Fe-deficient rats fed on diets $\mathrm{A}$ and $\mathrm{B}(P<0 \cdot 05)$.

Mean body weight was lowest in Fe-deficient animals fed on both diets $\mathrm{A}$ and $\mathrm{B}$ in comparison with their respective control groups (Table $2 ; P<0.001$ ).

\section{Food intake}

There was no significant difference in food intake between the control groups of rats given similar concentrations but different types of dietary Fe (ferric citrate in diet A, ferric citrate-bovine blood in diet B), despite the slight increase in animals fed on diet B. Intake 
Table 3. Digestive utilization of iron in control and Fe-deficient rats fed on diets with different sources of Fe§

(Mean values with their standard errors for seven rats)

\begin{tabular}{|c|c|c|c|c|c|c|c|c|c|c|}
\hline \multirow{2}{*}{$\begin{array}{l}\text { Treatment } \\
\text { group }\end{array}$} & \multicolumn{2}{|c|}{$\begin{array}{c}\text { Intake of diet } \\
\text { (g dry weight/rat } \\
\text { per } d)\end{array}$} & \multicolumn{2}{|c|}{$\begin{array}{c}\text { Intake Fe } \\
(\mathrm{mg} / \text { rat per } \mathrm{d})\end{array}$} & \multicolumn{2}{|c|}{$\begin{array}{c}\text { Faecal Fe } \\
(\mathrm{mg} / \text { rat per d) }\end{array}$} & \multicolumn{2}{|c|}{$\begin{array}{l}\text { Absorbed Fe } \\
(\mathrm{mg} / \text { rat per } \mathrm{d})\end{array}$} & \multicolumn{2}{|c|}{$\operatorname{ADC}(\%)$} \\
\hline & Mean & SE & Mean & $\mathrm{SE}$ & Mean & $\mathrm{SE}$ & Mean & $\mathrm{SE}$ & Mean & SE \\
\hline $\mathrm{C}-\mathrm{A}$ & $20 \cdot 6^{*}$ & 0.7 & 0.91 & 0.03 & $0 \cdot 81$ & 0.02 & $0 \cdot 10$ & 0.03 & $10 \cdot 4$ & $2 \cdot 6$ \\
\hline C-B & $21.9 \dagger$ & 0.5 & 0.97 & 0.02 & 0.84 & 0.03 & 0.13 & 0.02 & $13 \cdot 8$ & 1.9 \\
\hline $\mathbf{F}-\mathbf{A}$ & $16 \cdot 3 \ddagger$ & 0.4 & 0.70 & 0.02 & 0.64 & 0.02 & 0.10 & 0.01 & 14.8 & 1.6 \\
\hline F-B & $19 \cdot 3^{\circ}$ & 0.5 & 0.86 & 0.02 & 0.68 & 0.01 & 0.17 & 0.03 & $20 \cdot 1$ & $2 \cdot 6$ \\
\hline
\end{tabular}

C-A, semi-synthetic diet A (ferric citrate) for $30 \mathrm{~d}$ followed by diet $\mathrm{A}$ for experimental period; $\mathrm{C}-\mathrm{B}$, diet $\mathrm{A}$ for $30 \mathrm{~d}$ followed by diet $\mathbf{B}$ (ferric citrate-bovine blood) for experimental period; $\mathrm{F}-\mathrm{A}$, diet $\mathrm{O}$ (no Fe supplement) for $30 \mathrm{~d}$ followed by diet $\mathrm{A}$ for experimental period; $\mathrm{F}-\mathbf{B}$, diet $\mathrm{O}$ for $30 \mathrm{~d}$ followed by diet $\mathrm{B}$ for experimental period; $\mathrm{ADC}$, apparent digestibility coefficient.

Mean values were significantly different from those for $\mathrm{F}-\mathrm{A}:^{*} P<0.001$.

Mean values were significantly different from those for $\mathrm{F}-\mathrm{B}: \dagger P<0.05 ; P<0.01$.

$\S$ For details of diets, see Table 1 and p. 610 .

Table 4. Digestive utilization of phosphorus in control and iron-deficient rats fed on diets with different sources of $\mathrm{Fe}^{*}$

(Mean values with their standard errors for seven rats)

\begin{tabular}{|c|c|c|c|c|c|c|c|c|}
\hline \multirow{2}{*}{$\begin{array}{l}\text { Treatment } \\
\text { group }\end{array}$} & \multicolumn{2}{|c|}{$\begin{array}{c}\text { Intake } \mathrm{P} \\
\text { (mg/rat per d) }\end{array}$} & \multicolumn{2}{|c|}{$\begin{array}{c}\text { Faecal P } \\
(\mathrm{mg} / \text { rat per d) }\end{array}$} & \multicolumn{2}{|c|}{$\begin{array}{c}\text { Absorbed } P \\
(\mathrm{mg} / \text { rat per } \mathrm{d})\end{array}$} & \multicolumn{2}{|c|}{$\operatorname{ADC}(\%)$} \\
\hline & Mean & $\mathrm{SE}$ & Mean & $\mathrm{SE}$ & Mean & $\mathrm{SE}$ & Mean & $\mathrm{SE}$ \\
\hline $\mathrm{C}-\mathrm{A}$ & 92.83 & $3 \cdot 33$ & $45 \cdot 21$ & $3 \cdot 22$ & 47.62 & 1.44 & $51 \cdot 3$ & 1.79 \\
\hline $\mathrm{C}-\mathrm{B}$ & $128 \cdot 14$ & 2.95 & $57 \cdot 12$ & 3.82 & 71.02 & 4.01 & $55 \cdot 4$ & 2.78 \\
\hline $\mathrm{F}-\mathrm{A}$ & $72 \cdot 39$ & $2 \cdot 34$ & $38 \cdot 22$ & $1 \cdot 36$ & $34 \cdot 18$ & $2 \cdot 34$ & $47 \cdot 1$ & $2 \cdot 01$ \\
\hline $\mathrm{F}-\mathrm{B}$ & 113.33 & 2.72 & 58.65 & $1 \cdot 46$ & 54.68 & $3 \cdot 82$ & $48 \cdot 0$ & $2 \cdot 29$ \\
\hline
\end{tabular}

C-A, semi-synthetic diet A (ferric citrate) for $30 \mathrm{~d}$ followed by diet A for experimental period; C-B, diet A for $30 \mathrm{~d}$ followed by diet $\mathrm{B}$ (ferric citrate-bovine blood) for experimental period; F-A, diet $\mathrm{O}$ (no Fe supplement) for $30 \mathrm{~d}$ followed by diet $\mathrm{A}$ for experimental period; $\mathrm{F}-\mathrm{B}$, diet $\mathrm{O}$ for $30 \mathrm{~d}$ followed by diet $\mathrm{B}$ for experimental period; ADC, apparent digestibility coefficient.

* For details of diets, see Table 1 and p. 610.

was significantly lower in both groups of Fe-deficient rats in comparison with their respective control groups (Table $3 ; P<0.001$ and $P<0.05$ for diets $\mathrm{A}$ and $\mathrm{B}$ respectively), moreover the intake of Fe-deficient rats fed on diet A was significantly lower than those fed on diet $\mathrm{B}(P<0.01)$.

\section{ADC of iron, phosphorus, calcium and magnesium}

The ADC of Fe was lower in control rats given diet $\mathrm{A}$ than in control animals fed on diet $\mathrm{B}$, although the difference was not significant (10.4 (SE 2.6) v. 13.8 (SE 1.9); Table 3).

The ADC of $\mathrm{P}$ was similar in both control groups (Table 4), but the ADC of Ca and $\mathrm{Mg}$ were lower with diet B (Tables 5 and 6), although they were both within the normal range described for this species (Barrionuevo et al. 1989; Campos et al. 1989; López-Aliaga et al. 1990). 
Table 5. Digestive utilization of calcium in control and iron-deficient rats fed on diets with different sources of Fe§

(Mean values with their standard errors for seven rats)

\begin{tabular}{|c|c|c|c|c|c|c|c|c|}
\hline \multirow{2}{*}{$\begin{array}{l}\text { Treatment } \\
\text { group }\end{array}$} & \multicolumn{2}{|c|}{$\begin{array}{c}\text { Intake } \mathrm{Ca} \\
(\mathrm{mg} / \text { rat per } \mathrm{d})\end{array}$} & \multicolumn{2}{|c|}{$\begin{array}{c}\text { Faecal } \mathrm{Ca} \\
(\mathrm{mg} / \text { rat per d) }\end{array}$} & \multicolumn{2}{|c|}{$\begin{array}{l}\text { Absorbed } \mathrm{Ca} \\
(\mathrm{mg} / \text { rat per } \mathrm{d})\end{array}$} & \multicolumn{2}{|c|}{$\operatorname{ADC}(\%)$} \\
\hline & Mean & $\mathrm{SE}$ & Mean & $\mathrm{SE}$ & Mean & $\mathrm{SE}$ & Mean & $\mathrm{SE}$ \\
\hline $\mathrm{C}-\mathrm{A}$ & 108.48 & 3.88 & 67.77 & $4 \cdot 34$ & $40 \cdot 34$ & $2 \cdot 56$ & $37 \cdot 4^{*}$ & $2 \cdot 56$ \\
\hline $\mathrm{C}-\mathrm{B}$ & 131.07 & 3.01 & 88.23 & $3 \cdot 82$ & $42 \cdot 84$ & $2 \cdot 14$ & $32 \cdot 8 \dagger$ & 1.84 \\
\hline $\mathrm{F}-\mathrm{A}$ & 84.42 & 2.73 & 64.99 & $3 \cdot 11$ & 19.44 & 1.89 & $23 \cdot 1 t$ & $2 \cdot 31$ \\
\hline$F-B$ & 115.93 & 2.78 & $97 \cdot 51$ & $4 \cdot 10$ & $18 \cdot 32$ & $2 \cdot 23$ & $16 \cdot 0$ & 2.09 \\
\hline
\end{tabular}

C-A, semi-synthetic diet A (ferric citrate) for $30 \mathrm{~d}$ followed by diet $\mathrm{A}$ for experimental period; C-B, diet $\mathrm{A}$ for $30 \mathrm{~d}$ followed by diet $\mathrm{B}$ (ferric citrate-bovine blood) for experimental period; F-A, diet $\mathrm{O}$ (no Fe supplement) for $30 \mathrm{~d}$ followed by diet $\mathrm{A}$ for experimental period; $\mathrm{F}-\mathrm{B}$, diet $\mathrm{O}$ for $30 \mathrm{~d}$ followed by diet $\mathrm{B}$ for experimental period; ADC, apparent digestibility coefficient.

Mean value was significantly different from that for $\mathrm{F}-\mathrm{A}:{ }^{*} P<0.01$.

Mean value was significantly different from that for $\mathrm{F}-\mathrm{B}: \sharp P<0.05 ; \uparrow P<0.001$.

$\S$ For details of diets, see Table 1 and p. 610 .

Table 6. Digestive utilization of magnesium in control and iron-deficient rats fed on diets with different sources of $\mathrm{Fe} \S$

(Mean values with their standard errors for seven rats)

\begin{tabular}{|c|c|c|c|c|c|c|c|c|}
\hline \multirow{2}{*}{$\begin{array}{c}\text { Treatment } \\
\text { group }\end{array}$} & \multicolumn{2}{|c|}{$\begin{array}{c}\text { Intake } \mathrm{Mg} \\
(\mathrm{mg} / \text { rat per } \mathrm{d})\end{array}$} & \multicolumn{2}{|c|}{$\begin{array}{c}\text { Faecal Mg } \\
(\mathrm{mg} / \text { rat per d) }\end{array}$} & \multicolumn{2}{|c|}{$\begin{array}{l}\text { Absorbed } \mathrm{Mg} \\
\text { (mg/rat per d) }\end{array}$} & \multicolumn{2}{|c|}{$\operatorname{ADC}(\%)$} \\
\hline & Mean & SE & Mean & $\mathrm{SE}$ & Mean & $\mathrm{SE}$ & Mean & $\mathrm{SE}$ \\
\hline $\mathrm{C}-\mathrm{A}$ & 11.67 & 0.42 & $5 \cdot 10$ & $0 \cdot 35$ & 6.57 & $0 \cdot 11$ & $56 \cdot 3^{*}$ & 1.87 \\
\hline C-B & 11.63 & 0.27 & $5 \cdot 81$ & 0.32 & 5.82 & 0.27 & $50 \cdot 1 \dagger$ & $2 \cdot 22$ \\
\hline $\mathrm{F}-\mathrm{A}$ & $9 \cdot 10$ & 0.29 & $6 \cdot 32$ & $0 \cdot 15$ & $2 \cdot 78$ & $0 \cdot 26$ & $25 \cdot 1 \ddagger$ & 3.97 \\
\hline$F-B$ & $10 \cdot 29$ & 0.25 & $9 \cdot 19$ & 0.32 & $1 \cdot 10$ & 0.29 & $10 \cdot 6$ & $2 \cdot 78$ \\
\hline
\end{tabular}

C-A, semi-synthetic diet A (ferric citrate) for $30 \mathrm{~d}$ followed by diet $\mathbf{A}$ for experimental period; C-B, diet A for $30 \mathrm{~d}$ followed by diet $\mathrm{B}$ (ferric citrate-bovine blood) for experimental period; F-A, diet $\mathrm{O}$ (no Fe supplement) for $30 \mathrm{~d}$ followed by diet $\mathrm{A}$ for experimental period; F-B, diet $\mathrm{O}$ for $30 \mathrm{~d}$ followed by diet $\mathrm{B}$ for experimental period; ADC, apparent digestibility coefficient.

Mean value was significantly different from that for $\mathrm{F}-\mathrm{A}:{ }^{*} P<0.001$.

Mean value was significantly different from that for $\mathrm{F}-\mathrm{B}: \ddagger P<0.02 ; \uparrow P<0.001$.

$\S$ For details of diets, see Table 1 and p. 610 .

In both groups of Fe-deficient rats the $\mathrm{ADC}$ of $\mathrm{Fe}$ was higher than in the respective control group (percentage increases: diet A 42.3, diet B 45.7). The difference in the ADC between the two Fe-deficient groups was not significant (Table 3).

For $\mathrm{P}$ the $\mathrm{ADC}$ was lower in both groups of $\mathrm{Fe}$-deficient rats than in their respective control groups, although it remained within the normal range described for this species (Table 4). However, for $\mathrm{Ca}$ and $\mathrm{Mg}$ there were clear decreases in the ADC in Fe-deficient animals with both diets, in comparison with their respective control groups (Tables 5 and $6 ; P<0.001)$ except for the ADC of $\mathrm{Ca}$ in rats fed on diet $\mathrm{A}(P<0.01)$. Moreover the ADC of $\mathrm{Ca}$ and $\mathrm{Mg}$ of the Fe-deficient rats fed on diet $\mathrm{B}$ was lower than that of Fe-deficient rats fed on diet $\mathrm{A}(P<0.05$ and $P<0.02$ respectively $)$. 
Table 7. Haemoglobin $(H b)$ regeneration efficiency $(H R E)$ in control and iron-deficient rats fed on diets with different sources of $\mathrm{Fe} \|$

(Mean values with their standard errors for seven rats)

\begin{tabular}{|c|c|c|c|c|c|c|c|c|c|c|c|c|}
\hline \multirow{2}{*}{$\begin{array}{l}\text { Treatment } \\
\text { group }\end{array}$} & \multicolumn{2}{|c|}{$\begin{array}{c}\text { Intake Fe } \\
(\mathrm{mg})\end{array}$} & \multicolumn{2}{|c|}{$\begin{array}{c}\text { Initial body } \\
\text { wt (g) }\end{array}$} & \multicolumn{2}{|c|}{$\begin{array}{l}\text { Initial Hb } \\
(\mathrm{g} / \mathrm{l})\end{array}$} & \multicolumn{2}{|c|}{$\begin{array}{c}\text { Final body } \\
\text { wt (g) }\end{array}$} & \multicolumn{2}{|c|}{$\begin{array}{l}\text { Final Hb } \\
(\mathrm{g} / \mathrm{l})\end{array}$} & \multicolumn{2}{|c|}{ Hire $(\%)$} \\
\hline & Mean & $\mathrm{SE}$ & Mean & $\mathrm{SE}$ & Mean & $\mathrm{SE}$ & Mean & $\mathrm{SE}$ & Mean & SE & Mean & $S E$ \\
\hline $\mathrm{C}-\mathrm{A}$ & $6 \cdot 35$ & 0.2 & 237.5 & $2 \cdot 7$ & $179^{*}$ & 2 & $289 \cdot 5^{*}$ & $6 \cdot 1$ & 187 & 1 & $40.9 *$ & 1.8 \\
\hline $\mathrm{C}-\mathrm{B}$ & $6 \cdot 78$ & 0.2 & $248 \cdot 6$ & $4 \cdot 4$ & $178 \dagger$ & 2 & $302 \cdot 0 \dagger$ & $4 \cdot 2$ & $187 \dagger$ & 1 & $40 \cdot 5 \dagger$ & 06 \\
\hline $\mathrm{F}-\mathrm{A}$ & 4.88 & $0 \cdot 2$ & 221.9 & $10 \cdot 8$ & 50 & 2 & $239 \cdot 1 f$ & $8 \cdot 1$ & $111 \S$ & 2 & $70 \cdot 7 \ddagger$ & $2 \cdot 7$ \\
\hline $\mathrm{F}-\mathrm{B}$ & 600 & $0 \cdot 1$ & 246.6 & $4 \cdot 0$ & 47 & 4 & $262 \cdot 9^{+}$ & $4 \cdot 6$ & 123 & 4 & $77 \cdot 4^{+}$ & 1.2 \\
\hline
\end{tabular}

C-A, semi-synthetic diet A (ferric citrate) for $30 \mathrm{~d}$ followed by diet $\mathbf{A}$ for experimental period; C-B, diet $\mathbf{A}$ for $30 \mathrm{~d}$ followed by diet $\mathbf{B}$ (ferric citrate-bovine blood) for experimental period; F-A, diet $\mathrm{O}$ (no Fe supplement) for $30 \mathrm{~d}$ followed by diet $\mathrm{A}$ for experimental period; F-B, diet $\mathrm{O}$ for $30 \mathrm{~d}$ followed by diet $\mathrm{B}$ for experimental period.

Mean values were significantly different from those for $\mathrm{F}-\mathrm{A}:{ }^{*} P<0.001$.

Mean values were significantly different from those for $\mathrm{F}-\mathrm{B}: \ddagger P<0.05 ; \S P<0.02 ; \dagger P<0.001$.

$\|$ For details of diets, see Table 1 and p. 610 .

Table 8. Serum values of iron, calcium and phosphorus in control and Fe-deficient rats fed on diets with different sources of Fe\|

(Mean values with their standard errors for seven rats)

\begin{tabular}{|c|c|c|c|c|c|c|}
\hline \multirow{2}{*}{$\begin{array}{l}\text { Treatment } \\
\text { group }\end{array}$} & \multicolumn{2}{|c|}{$\mathrm{Fe}(\mu \mathrm{g} / \mathrm{l})$} & \multicolumn{2}{|c|}{$\mathrm{Ca}(\mathrm{mg} / \mathrm{l})$} & \multicolumn{2}{|c|}{$\mathrm{P}(\mathrm{mg} / \mathrm{l})$} \\
\hline & Mean & SE & Mean & $\mathrm{SE}$ & Mean & $\mathrm{SE}$ \\
\hline $\mathrm{C}-\mathrm{A}$ & $900^{*}$ & 199 & $96 \dagger$ & I & $58.2 \dagger$ & 1 \\
\hline $\mathrm{C}-\mathrm{B}$ & $930 \ddagger$ & 120 & 100 & 1 & $59 \cdot 7 \S$ & 2 \\
\hline $\mathrm{F}-\mathrm{A}$ & 60 & 14 & 103 & 1 & $65.9^{\circ}$ & 1 \\
\hline$F-B$ & 80 & 21 & 102 & 1 & $65 \cdot 7$ & 0.4 \\
\hline
\end{tabular}

C-A, semi-synthetic diet A (ferric citrate) for $30 \mathrm{~d}$ followed by diet $\mathrm{A}$ for experimental period; C-B, diet $\mathrm{A}$ for $30 \mathrm{~d}$ followed by diet $\mathbf{B}$ (ferric citrate bovine blood) for experimental period; $\mathrm{F}-\mathrm{A}$, diet $\mathrm{O}$ (no $\mathrm{Fe}$ supplement) for $30 \mathrm{~d}$ followed by diet $\mathrm{A}$ for experimental period; $\mathrm{F}-\mathrm{B}$, diet $\mathrm{O}$ for $30 \mathrm{~d}$ followed by diet $\mathbf{B}$ for experimental period.

Mean values were significantly different from those for $\mathrm{F}-\mathrm{A}: \uparrow P<0.02 ;{ }^{*} P<0.001$.

Mean values were significantly different from those for $\mathrm{F}-\mathrm{B}: \S P<0.05 ; \ddagger P<0.001$.

I| For details of diets, see Table 1 and p. 610.

\section{Haematological studies}

Percentage HRE was similar in control rats that consumed diet $A$ and animals given diet B (diet A 40.9 (SE 1.8), diet B 40.5 (SE 0.6); Table 7). These results were also similar to those reported by other authors.

The percentage increases in HRE in Fe-deficient animals were 72.9 (diet A) and $91 \cdot 1$ (diet B; Table 7; $P<0.001$ ).

Serum levels of Fe decreased markedly in both groups of Fe-deficient rats $(P<0.001)$, whereas neither of the diets modified calcaemia or phosphataemia which were within the normal values for this species (Charles River Laboratories, 1982). However, there were differences between groups $(P<0.02$ for control group rats $v$. Fe-deficient rats fed on diet A; Table 8 ) for values of calcaemia and phosphataemia. 
Table 9. Erythrocytes $(R B C)$, haemoglobin $(H b)$ and packed cell volume $(P C V)$ in control and iron-deficient rats fed on diets with different sources of $\mathrm{Fe} \|$

(Mean values with their standard errors for seven rats)

\begin{tabular}{|c|c|c|c|c|c|c|c|c|c|c|c|c|}
\hline \multirow{3}{*}{$\begin{array}{l}\text { Treatment } \\
\text { group }\end{array}$} & \multicolumn{4}{|c|}{$\mathrm{RBC}\left(\times 10^{6} / \mathrm{mm}^{3}\right)$} & \multicolumn{4}{|c|}{$\mathrm{Hb}(\mathrm{g} / \mathrm{l})$} & \multicolumn{4}{|c|}{$\operatorname{PCV}(\%)$} \\
\hline & \multicolumn{2}{|c|}{ Initial } & \multicolumn{2}{|c|}{ Final } & \multicolumn{2}{|c|}{ Initial } & \multicolumn{2}{|c|}{ Final } & \multicolumn{2}{|c|}{ Initial } & \multicolumn{2}{|c|}{ Final } \\
\hline & Mean & $\mathrm{SE}$ & Mean & $\mathrm{SE}$ & Mean & $\mathrm{SE}$ & Mean & $\mathrm{SE}$ & Mean & $\mathrm{SE}$ & Mean & $\mathrm{SE}$ \\
\hline $\mathrm{C}-\mathrm{A}$ & $7 \cdot 4^{*}$ & $0 \cdot 2$ & $7-8^{*}$ & 0.3 & $17 \cdot 9^{*}$ & 0.2 & $18 \cdot 7^{*}$ & $0 \cdot 1$ & $41^{*}$ & 0.4 & 48 & 1.7 \\
\hline $\mathrm{C}-\mathrm{B}$ & $7.7 \ddagger$ & $0 \cdot 2$ & $8 \cdot 1 \ddagger$ & 0.3 & $17 \cdot 8 \ddagger$ & $0 \cdot 2$ & $18 \cdot 7 \ddagger$ & $0 \cdot 1$ & $43 \ddagger$ & 1.0 & $51 \ddagger$ & $1 \cdot 5$ \\
\hline $\mathrm{F}-\mathrm{A}$ & 1.9 & $0 \cdot 1$ & $5 \cdot 8$ & $0 \cdot 1$ & 5.0 & $0 \cdot 2$ & $11 \cdot 1 \S$ & $0 \cdot 2$ & $16^{\circ}$ & 0.5 & $41^{\circ}$ & $1 \cdot 3$ \\
\hline F-B & $1 \cdot 9$ & $0 \cdot 1$ & $5 \cdot 1$ & $0 \cdot 1$ & $4 \cdot 7$ & 0.4 & $12 \cdot 3$ & $0 . \overline{4}$ & 18 & 0.8 & 39 & 0.2 \\
\hline
\end{tabular}

C-A, semi-synthetic diet A (ferric citrate) for $30 \mathrm{~d}$ followed by diet A for experimental period; C-B, diet A for $30 \mathrm{~d}$ followed by diet $\mathrm{B}$ (ferric citrate-bovine blood) for experimental period; $\mathrm{F}-\mathrm{A}$, diet $\mathrm{O}$ (no Fe supplement) for $30 \mathrm{~d}$ followed by diet A for experimental period; F-B, diet $\mathrm{O}$ for $30 \mathrm{~d}$ followed by diet $\mathrm{B}$ for experimental period.

Mean values were significantly different from those for $\mathrm{F}-\mathrm{A}: \dagger P<0.02 ; * P<0.001$.

Mean value was significantly different from that for $\mathrm{F}-\mathrm{B}: \S P<0.02 ; \ddagger P<0.001$.

$\|$ For details of diets, see Table 1 and p. 610 .

Table 10. Leucocyte (WBC) count and WBC index (percentage of each type of $W B C$, referred to the total number of $W B C$ identified) in control and iron-deficient rats fed on diets with different sources of Fe

(Mean values with their standard errors for seven rats)

\begin{tabular}{|c|c|c|c|c|c|c|c|c|c|}
\hline \multirow[t]{2}{*}{ Treatment group ... } & & \multicolumn{2}{|c|}{$\mathrm{C}-\mathrm{A}$} & \multicolumn{2}{|c|}{$\mathrm{C}-\mathrm{B}$} & \multicolumn{2}{|c|}{$\mathbf{F}-\mathbf{A}$} & \multicolumn{2}{|c|}{$\mathrm{F}-\mathrm{B}$} \\
\hline & & Mean & $\mathrm{SE}$ & Mean & $\mathrm{SE}$ & Mean & $\mathrm{SE}$ & Mean & SE \\
\hline \multirow[t]{2}{*}{ WBC $\left(10^{3} / \mathrm{mm}^{3}\right)$ : } & Initial & $15 \cdot 5$ & $1 \cdot 4$ & $12 \cdot 4$ & 0.7 & $10 \cdot 0$ & $0 \cdot 1$ & $9 \cdot 4$ & $0 \cdot 1$ \\
\hline & Final & $9 \cdot 4$ & 0.2 & 8.8 & 0.2 & $8 \cdot 4$ & $0 \cdot 3$ & $10 \cdot 1$ & $0 \cdot 1$ \\
\hline \multirow[t]{2}{*}{ Neutrophils $(\%)$ : } & Initial & 17 & $0 \cdot 4$ & 18 & 0.5 & 18 & 0.9 & 18 & $0 \cdot 3$ \\
\hline & Final & 19 & 0.4 & 22 & 1.8 & 16 & $0 \cdot 2$ & 19 & $1 \cdot 6$ \\
\hline \multirow[t]{2}{*}{ Band forms $(\%)$ : } & Initial & 0 & 0 & 0 & 0 & 0 & & 0 & \\
\hline & Final & 0 & 0 & 1 & $0 \cdot 2$ & 0 & & 0 & \\
\hline \multirow{2}{*}{ Lymphocytes $(\%)$ : } & Initial & 81 & $1 \cdot 2$ & 79 & 1.0 & 80 & $1 \cdot 3$ & 80 & $0 \cdot 9$ \\
\hline & Final & 76 & $1 \cdot 6$ & 73 & $2 \cdot 3$ & 80 & 0.5 & 74 & $2 \cdot 2$ \\
\hline \multirow[t]{2}{*}{ Monocytes (\%): } & Initial & 2 & $0 \cdot 1$ & 1 & $0 \cdot 3$ & 1 & 0.4 & 1 & 0.3 \\
\hline & Final & 4 & $1 \cdot 2$ & 4 & 0.4 & 5 & 0.4 & 5 & $0 \cdot 8$ \\
\hline \multirow[t]{2}{*}{ Eosinophils $(\%)$ : } & Initial & 0 & $0 \cdot 3$ & 2 & $0 \cdot 1$ & 0 & 0.2 & 1 & $0 \cdot 3$ \\
\hline & Final & 1 & $0 \cdot 5$ & 0 & $0 \cdot 4$ & 0 & & 2 & $0 \cdot 7$ \\
\hline \multirow{2}{*}{ Basophils $(\%)$ : } & Initial & 0 & & 0 & & 0 & & 0 & \\
\hline & Final & 0 & & 0 & & 0 & & 0 & \\
\hline
\end{tabular}

C-A, semi-synthetic diet A (ferric citrate) for $30 \mathrm{~d}$ followed by diet A for experimental period; C-B, diet A for $30 \mathrm{~d}$ followed by diet $\mathrm{B}$ (ferric citrate-bovine blood) for experimental period; $\mathrm{F}-\mathrm{A}$, diet $\mathrm{O}$ (no Fe supplement) for $30 \mathrm{~d}$ followed by diet $\mathrm{A}$ for experimental period; $\mathrm{F}-\mathrm{B}$, diet $\mathrm{O}$ for $30 \mathrm{~d}$ followed by diet $\mathrm{B}$ for experimental period.

Erythrocytes, packed cell volume and haemoglobin in control rats were within normal limits for this species (Charles River Laboratories, 1982) before and after the experimental period (Table 9).

Fe-deficient rats showed an almost complete recovery of packed cell volume after consuming either diet $\mathrm{A}$ or diet B. Erythrocyte numbers and haemoglobin levels also recovered, but failed to reach the control values recorded with either of the diets. There were 
no differences between Fe-deficient animals fed on diet A or diet B in any of the haematological results, except in the final haemoglobin concentration (Table $9 ; P<0 \cdot 02$ ).

Leucocyte counts and leucocyte indices were within normal limits for the rat in both controls and Fe-deficient animals, regardless of the source of dietary Fe provided (Table $10)$.

\section{DISCUSSION}

The lower food intake in Fe-deficient rats regardless of the diet consumed may have been due to the behavioural effects (e.g. anorexia) of lack of $\mathrm{Fe}$, as described in anaemia (Coltman, 1969).

The ADC of $\mathrm{Fe}$ was higher in animals that consumed diet $\mathrm{B}$, in agreement with earlier findings of Gordon \& Godber (1989) and Shah et al. (1983) who reported that a mixture of inorganic and organic Fe increased the bioavailability of this element.

The ADC of $\mathrm{Fe}$ in control animals was notably lower than the values reported by Zhang et al. (1989, 1991), possibly because of the different sources of dietary Fe. According to Brise \& Hallberg (1962), the absorption of ferric citrate, measured in the present study, is much lower than that of ferrous sulphate, used by Zhang et al. $(1989,1991)$. Another difference with respect to the present study is that Zhang et al. $(1989,1991)$ used young rats (body weight $90 \mathrm{~g}$ ), in which the utilization of $\mathrm{Fe}$ and other nutrients is higher than that in adult rats (body weight $256 \mathrm{~g}$ ), which have lower nutritional requirements. Our choice of ferric citrate as the Fe supplement was based on the guidelines of the American Institute of Nutrition (1977) for mineral supplements. The lower digestive utilization of $\mathrm{Fe}$ in the present study may also be related to the lower dietary supply of protein $(120$ and $123 \mathrm{~g} / \mathrm{kg}$ in diets $\mathrm{A}$ and $\mathrm{B}$ respectively), which nevertheless was considered sufficient to cover the requirements of adult rats (Thomas \& Mitchell, 1923), and suitable for testing the experimental interrelationships between $\mathrm{Fe}$ and protein. In this connection, Gordon \& Godber (1989) noted that Fe absorption was affected by both the amount and the quality of the protein tested. In addition, the greater ADC of Fe in animals that consumed diet B (which, due to the addition of bovine blood, contained slightly more protein than diet $\mathrm{A}$ ) suggests that once the minimum dietary Fe requirement is satisfied any variation in the quantity or quality of this nutrient will be reflected in the ADC of Fe.

Percentage HRE in both groups of control rats was similar to that reported by other authors (Miller \& Nnanna, 1983; Thannoun et al. 1987 a; Zhang et al. 1989, 1991). That HRE was normal in our rats despite their lower digestive utilization of Fe may have been due to the higher turnover of circulating Fe under our experimental conditions, as suggested by the fact that our values for serum Fe, number of erythrocytes and haemoglobin concentration were similar to those reported for Wistar rats in a previous publication (Charles River Laboratories, 1982).

The increase in percentage ADC of Fe in deficient rats fed on diet A (ferric citrate) or diet B (haem-plus non-haem-Fe) was similar to that reported by Thannoun et al. $(1987 \mathrm{a})$. However, digestive utilization of Fe was greater with diet $B$ than with diet $A$, probably for the same reasons as given previously with reference to the control group. The greater digestive utilization of $\mathrm{Fe}$ by anaemic rats was reflected in the HRE, which increased markedly to $70.7 \%$ after diet $\mathrm{A}$ and to $77.4 \%$ after diet $\mathrm{B}$. These values were also similar to those obtained in many earlier studies (Park et al. 1983; Jansuittivechakul et al. 1985, 1986; Thannoun et al. $1987 a$, b; Gordon \& Godber, 1989; Zhang et al. 1989, 1991).

The decrease in serum concentrations of Fe in both groups of Fe-deficient rats concurs with the findings of Schümann et al. (1989) that, in spite of the better digestive utilization of $\mathrm{Fe}$ and the fact that haemoglobin levels were nearly adequate, serum Fe remained low regardless of the type of dietary Fe supplied. This suggests that Fe reserves in these animals 
had not fully recovered, despite the apparent recovery of haematological indicators of $\mathrm{Fe}$ nutrient status.

The digestive utilization of $\mathrm{P}$ by Fe-deficient rats was lower in both groups than in their respective controls, indicating that $\mathrm{Fe}$ deficiency affected the nutritional utilization of $\mathrm{P}$ even though the ADC of $\mathrm{P}$ was within the normal values, as reported also by Gordon \& Godber (1989). However, the ADC of both $\mathrm{Ca}$ and $\mathrm{Mg}$ decreased significantly in Fedeficient animals regardless of the source of dietary Fe. This finding can be interpreted in the light of evidence provided by Zhang et al. (1989) with regard to $\mathrm{Fe}$ absorption: these authors noted that in anaemic rats absorption by binding proteins was diminished, leading to increased enterocyte uptake of Fe (supplied as ferric citrate) by diffusion. This increase, in turn, probably left a greater amount of citrate anion in the intestinal lumen, where it could bind with $\mathrm{Ca}$ or $\mathrm{Mg}$ to form less readily absorbed divalent compounds of these cations (López de Novales, 1974).

This hypothesis would also account for the reduced $\mathrm{Ca}$ and $\mathrm{Mg}$ absorption in animals that consumed diet $\mathrm{B}$. The greater absorption of Fe probably involved Fe supplied in the form of ferric citrate; consequently, the larger amount of free anion remaining in the intestinal lumen would favour the increased formation of calcium citrate and magnesium citrate compounds, thus decreasing the absorption of these cations.

The validity of the findings presented previously could be called into question if it were shown that the rats suffered from some infectious process during the experiments. This was ruled out by the quantitative and qualitative studies of circulating leucocytes in both control and experimental subjects. In all four groups investigated leucoctye count and leucocyte index remained within the limits considered normal, given some degree of biological variability.

The interrelationships reported here between Fe nutrition and the digestive utilization of $\mathrm{Fe}, \mathrm{Ca}, \mathrm{P}$ and $\mathrm{Mg}$ point toward a potentially fruitful new avenue of research in anaemia. Moreover, as noted by Gordon \& Godber (1989), the results obtained with this model may, with the necessary caveats, be extrapolated to human nutrition.

The study was supported by the CICYT through Project no. ALI90-0616. The authors thank Ms Elisa Alcover for her expert secretarial assistance, Ms Rosa Jiménez and Ms Rosalía Romero for their competent technical assistance, and Ms Karen Shashok for translating the original manuscript into English.

\section{REFERENCES}

American Institute of Nutrition (1977). Report of the AIN Ad Hoc Committee on standards for nutritional studies. Journal of Nutrition 107, 1340-1348.

Apte, S. V. \& Venkatachalam, P. S. (1964). The influence of dietary calcium on absorption of iron. Indian Journal of Medical Research 52, 213-218.

Barrionuevo, M., Campos, M. S., López-Aliaga, I., Coves, F. \& Lisbona, F. (1989). Nutritive utilization of phosphorus in the rat: influence of intestinal resection and dietary medium chain triglycerides and vitamin $D_{3}$. International Journal for Vitamin and Nutrition Research 59, 255-261.

Beutler, E. (1988). Minerales Principales: Hierro. In La Nutrición en la Salud y en la Enfermedad (Modern Nutrition in Health and Disease, 6th ed.) pp. 298-326 [Y. Ruckenbush and P. Thivend, editors]. Barcelona: Salvat.

Brise, H. \& Hallberg, L. (1962). Iron absorption studies. II. A method for comparative studies on iron absorption in man using two radioiron isotopes. Acta Medica Scandinavica 171, Suppl., 7-22.

Campos, M. S., López-Aliaga, I., Barrionuevo, M., Lisbona, F. \& Coves, F. (1989), Nutritive utilization of calcium in rats: influence of intestinal resection and type of diet. Journal of Nutritional Science and Vitaminology 35, 511-521.

Charles River Laboratories (1982). Technical Bulletin, vol. 1, no. 2. Wilmington, Massachusetts: The Charles River Laboratories.

Coltman, C. A. (1969). Pagophagia and iron lack. Journal of the American Medical Association 207, 513-516. 
Conrad, M. E. \& Barton, J. C. (1978). Factors affecting the absorption and excretion of lead in the rat. Gastroenterology 74, 731-740.

Dawson-Hughes, B., Seligson, F. H. \& Hughes, V. A. (1986). Effects of calcium carbonate and hydroxyapatite on zinc and iron retention in postmenopausal women. American Journal of Clinical Nutrition 44, 83-88.

Deehr, M. S., Dallal, G. E., Smith, K. T., Taulbee, J. D. \& Dawson-Hughes, B. (1990). Effects of different calcium sources on iron absorption in postmenopausal women. American Journal of Clinical Nutrition 51, 95-99.

Drewes, P. A. (1972). Direct colorimetric determination of phosphorus in serum and urine. Clinica Chimica Acta 39, 81-88.

Fiske, C. H. \& Subbarow, Y. (1925). The colorimetric determination of phosphorus. Journal of Biological Chemistry 66, 375-400.

Flanagan, P. R., Haist, J. \& Valberg, L. S. (1980). Comparative effects of iron deficiency induced by bleeding and a low iron diet on the intestinal absorptive interactions of iron, cobalt, manganese, zinc, lead and cadmium. Journal of Nutrition 110, 1754-1763.

Flanagan, P. R., McLellan, J. S., Haist, J., Cherian, M. G., Chamberlain, M. J. \& Valberg, L. S. (1978). Increased dietary absorption in mice and human subjects with iron deficiency. Gastroenterology 74, 841-846.

Gordon, D. T. \& Godber, J. S. (1989). The enhancement of nonheme iron bioavailability by beef protein in the rat. Journal of Nutrition 119, 446452.

Hallberg, L., Bjorn-Rasmussen, E., Howard L. \& Rossander, L. (1979). A discussion of possible mechanisms for the absorption-promotion effect of meat and for the regulation of iron absorption. Scandinavian Journal of Gastroenterology 14, 769-779.

Hamilton, D. L., Bellamy, J. E. C., Valberg, J. D. \& Valberg, L. S. (1978). Zinc, cadmium and iron interactions during intestinal absorption in iron-deficient mice. Canadian Journal of Physiology and Pharmacology 56, 384-389.

Jansuittivechakul, O., Mahoney, A. W., Cornforth, D. P. \& Hendricks, D. G. (1985). Effect of heat treatment on bioavailability of meat and hemoglobin iron fed to anemic rats. Journal of Food Science 50, 407-409.

Jansuittivechakul, O., Mahoney, A. W., Cornforth, D. P., Hendricks, D. G. \& Sisson, D. V. (1986). Effect of heat treatment on meat enhancement of dietary iron bioavailability of meat, ferrous sulfate and meat/hemoglobin mixtures fed to anemic rats. Journal of Food Science 51, 263-267.

Layrisse, M., Cook, J. D., Martinez-Torres, C., Roche, M., Kuhn, I. N., Walker, R. B. \& Finch, C. A. (1969). Food iron absorption: a comparison of vegetable and animal foods. Blood 33, 430-443.

Layrisse, M., Martinez-Torres, C. \& Roche, M. (1968). Effect on interaction of various foods on iron absorption. American Journal of Clinical Nutrition 21, 1175-1183.

Lönnerdal, B. (1989). Trace element absorption in infants as a foundation to setting upper limits for trace elements in infant formulas. Journal of Nutrition 119, 1839-1845.

LönnerdaJ, B., Keen, C. L. \& Hurley, L. S. (1981). Iron, copper and manganese in milk. Annual Review of Nutrition 1, 149-174.

López Aliaga, I., Barrionuevo, M., Campos, M. S., Coves, F. \& Lisbona, F. (1990). Influence of intestinal resection and type of diet on digestive and metabolic utilization of magnesium. International Journal for Vitamin and Nutrition Research 61, 61-66.

López de Novales, E. (1974). Metabolismo mineral del magnesio (Mineral metabolism of magnesium). Revista Clínica Española 135, 307-312.

Mahoney, A. W. \& Hendricks, D. G. (1984). Potential of the rat as a model for predicting iron bioavailability for humans. Nutrition Research 4, 913-922.

Mahoney, A. W., Whittaker, P., Farmer, B. R. \& Hendricks, D. G. (1985). Iron bioavailability in an anemic rat model: effect of food restriction. Nutrition Reports International 31, 457-462.

Martinez-Torres, C. \& Layrisse, M. (1971). Iron absorption from veal muscle. American Journal of Clinical Nutrition 24, 531-540.

Martinez-Torres, C., Leets, I., Taylor, P., Ramirez, J., Camacho, M. V. \& Layrisse, M. (1986). Heme, ferritin and vegetable iron absorption in humans from meals denatured of heme iron during the cooking of beef. Journal of Nutrition 116, 1720-1725.

Miller, J. \& Nnanna, I. (1983). Bioavailability of iron in cooked egg yolk for maintenance of hemoglobin levels in growing rats. Journal of Nutrition 113, 1169-1175.

Monsen, E. R. \& Cook, J. D. (1976). Food-iron absorption in human subjects. IV. The effects of calcium and phosphate salts on the absorption of nonheme iron. American Journal of Clinical Nutrition 29, 1142-1148.

O'Dell, B. L. (1989). Mineral interactions relevant to nutrient requirements. Journal of Nutrition 119, $1832-1838$.

Park, Y. W., Mahoney, A. W. \& Hendricks, D. G. (1983). Bioavailability of different sources of ferrous sulfate iron fed to anemic rats. Journal of Nutrition 113, 2223-2228.

Sarkar, B. C. R. \& Chauhan, U. P. S. (1967). A new method for determining micro quantities of calcium in biological materials. Analytical Biochemistry 20, 155-166.

Schümann, K., Elsenhans, B., Hunder, G., Strugala, G. \& Forth, W. (1989). Increase of the intestinal iron absorption in growing rats and mice after 8 days of iron-deficient feedings Zeitschrift für Versuchungstierkunde 32, 261-267.

Shah, B. G., Giroux, A. \& Belonje, B. (1983). Bioavailability of iron in ground beef and plant protein concentrates. Nutrition Research 3, 547-555. 
Snedeker, S. M., Smith, S. A. \& Greger, J. L. (1982). Effect of dietary calcium and phosphorus levels on the utilization of iron, copper and zinc by adult males. Journal of Nutrition 112, 136-143.

Solomons, N. W., Pineda, O., Viteri, F. \& Sanstead, H. H. (1983). Studies on the bioavailability of zinc in humans: mechanism of the intestinal interaction of nonheme iron and zinc. Journal of Nutrition 113, 337-349.

Thannoun, A. M., Mahoney, A. W. \& Hendricks, D. G. (1987a). Hemoglobin regeneration and iron absorption from meat loaf diets fed to anemic and healthy rats. Nutrition Reports International 36, 1273-1284.

Thannoun, A. M., Mahoney, A. W., Hendricks, D. G. \& Zhang, D. (1987 b). Effect of meat-bread mixtures on bioavailability of total dietary iron for anemic rats. Cereal Chemistry 64, 399-403.

Thomas, K. \& Mitchell, H. H. (1923). A method of determining the biological value of protein. Journal of Biological Chemistry 58, 873-903.

Thompson, A. B. R., Olatunbosun, P. \& Valberg, L. S. (1971a). Interrelation of intestinal transport system for manganese and iron. Journal of Laboratory and Clinical Medicine 78, 642-655.

Thompson, A. B. R., Shaver, C., Lee, D. J., Jones, B. L. \& Valberg, L. S. (1971 b). Effects of varying iron stores on sites of intestinal absorption of cobalt and iron. American Journal of Physiology 220, 674-678.

Trinder, P. (1956). The improved determination of iron in serum. Journal of Clinical Pathology 9, 170-172.

Weibull, M. Z. \& Berntrop, J. C. Z. (1988). Determination of fat matter. Weibull-Berntrop's gravimetric method. Brussels: Norme FIL Internationale.

Zhang, D., Hendricks, D. G. \& Mahoney, A. W. (1989). Bioavailability of total iron from meat, spinach (Spinacea olevacea L.) and meat-spinach mixtures by anaemic and non-anaemic rats. British Journal of Nutrition $\mathbf{6 1}$, 331-343.

Zhang, D., Hendricks, D. G., Mahoney, A. W., Yu, Y., Thannoun, A. M. \& Sisson, D. V. (1991). Bioavailability of total dietary iron from beef and soy protein isolate, alone or combined in anaemic and healthy rats. Cereal Chemistry 68, 194-200. 